\title{
Lokal ileri Evre Böbrek Tümörlerinde Adjuvan ve Neoadjuvan Hedefe Yönelik Tedaviler
}

\section{Adjuvant and Neoadjuvant Targeted Therapies in Locally Advanced Renal Cell Carcinoma}

\author{
Dr. Ozan Bozkurt, Dr. Ömer Demir \\ Dokuz Eylül Üniversitesi Tıp Fakültesi, Üroloji Anabilim Dalı, lzmir, Türkiye
}

\section{Özet}

Hedefe yönelik tedavilerin metastatik böbrek tümörlerinde immunoterapiye göre belirgin sağkalım avantajı sağlaması bu ajanların metastatik olmayan ve özellikle nüks açısından yüksek riskli lokal ileri evre böbrek tümörlerinde adjuvan ve neoadjuvan kullanımını gündeme getirmiştir. Bu derlemede metastatik olmayan böbrek tümörlerinde adjuvan ve neoadjuvan hedefe yönelik tedavilerle ilgili çalışmalar gözden geçirilecektir. Bugün için metastatik olmayan böbrek tümörlerinde adjuvan veya neoadjuvan hedefe yönelik tedavinin genel ya da nükssüz sağkalımı arttırdığına dair bir bulgu yoktur. Devam etmekte olan ve nüks riski açısından standardize skorlama sistemleri kullanan adjuvan tedavi çalışmaları hedefe yönelik tedavilerin bu alanda kullanımı ile ilgili daha net bilgiler sağlayacak ve hangi hasta gruplarında adjuvan tedavi gerektiğini belirlememize yardımcı olacaktır. Neoadjuvan hedefe yönelik tedaviler opere edilemeyeceği düşünülen, yüksek morbidite ve mortaliteye sahip hastalarda veya mutlak parsiyel nefrektomi gereksinimi olan hastalarda kısıtıla olsa fayda gösterebilmektedir. Bugün için metastatik olmayan böbrek tümörlerinde adjuvan ve neoadjuvan hedefe yönelik tedavilerin deneysel olduğu kabul edilmektedir. Lokalize ve lokal ileri evre RCC'de devam etmekte olan adjuvan ve neoadjuvan hedefe yönelik tedavi çalışmalarının sonuçları bize hem etkinlik hem de tedavi güvenliği açısından daha net bilgiler sağlayacaktır. (Üroonkoloji Bülteni 2014;13:139-145)

Anahtar Kelimeler: Böbrek tümörü, hedefe yönelik tedavi, adjuvan, neoadjuvan

\begin{abstract}
Summary
More successful treatment of metastatic renal cell carcinoma with targeted therapies compared to immunotherapy brought the idea of adjuvant and neoadjuvant use of these agents especially in locally advanced kidney tumors with high risk of recurrence. Clinical trials regarding adjuvant and neoadjuvant targeted therapies for nonmetastatic renal cell carcinoma will be discussed in this review. Today, there is no data demonstrating overall or disease-free survival advantages of adjuvant or neoadjuvant targeted therapies in non-metastatic renal cell carcinoma. Ongoing clinical adjuvant trials which mostly use standardized scoring systems for relapse risk stratification will both provide more clear information for us and also help us for establishing which patients groups need adjuvant therapy. Neoadjuvant targeted therapies for nonmetastatic renal cell carcinoma may have some limited value for tumors that are considered to be unresectable, for tumors with high morbidity and mortality rates if operated and also for tumors with absolute indication for partial nephrectomy. Targeted therapies in the adjuvant and neoadjuvant settings for patients with non-metastatic renal cell carcinoma is still experimental. Results of the ongoing adjuvant and neoadjuvant clinical trials with localised and locally advanced renal cell carcinoma will better inform us about the efficacy and safety of targeted therapies. (Bulletin of Urooncology 2014;13:139-145)
\end{abstract}

Key Words: Kidney cancer, targeted therapy, adjuvant, neoadjuvant

\section{Giriş}

Böbrek tümörlerinin (Renal cell carcinoma-RCC) insidansı gün geçtikçe artmaktadır. Global kanser istatistiklerine göre 2008 yılında tüm dünyada tahmini RCC insidansı yıllık 271,000 olgu olarak rapor edilmiştir (1). Ultrasonografi (USG), bilgisayarlı tomografi (BT) ve manyetik rezonans görüntüleme (MRG) gibi görüntüleme yöntemlerinin yaygınlaşması RCC'nin rastlantısal olarak saptanmasındaki artışı beraberinde getirmiş; bunun sonucu olarak birçok hasta erken evrede tanı almaya başlamıştır (2). Tanı anında hastaların \%50,6'sı evre I, \%26,7'si evre II ve III ve $\% 22,7^{\prime}$ si evre IV (metastatik) RCC'dir (3). Açık ya da laparoskopik cerrahi rezeksiyonun (parsiyel veya radikal nefrektomi) RCC tanısı alan ve metastazı olmayan hastaların önemli bir kısmında 
kür sağladığı bilinmektedir. Cerrahi sonrasında evre I RCC hastalarının 5 yıllık sağkalım oranı \%90'ın üzerindedir; bunun yanında evre II veya III RCC hastalarında cerrahi eksizyon sonrası 5 yıllık nüks oranları \%30-\%40 aralığındadır (4). Adjuvan tedavi ile özellikle nüks açısından riskli olgularda nüks oranlarının azaltılması ve sağkalımın uzatılması bugün diğer tüm solid tümörlerde olduğu gibi RCC tedavisinde de önemli hedeflerden birisidir. Neoadjuvan tedavinin amacı ise sağkalımın uzatılması, hastalığın metastatik yayılımını önlemek ve cerrahi rezeksiyonu kolaylaştırmak için tümör boyutlarında küçülme sağlamaktır.

Hedefe yönelik tedavilerin metastatik hastalıkta kullanıma girmesinden önce metastatik RCC'de standart tedavi interferonalfa (IFN- $\alpha$ ) ve interlökin-2'den (IL-2) oluşan sitokin bazlı immunoterapiydi. İmmunoterapi ile metastatik RCC'de hastaların $\% 15$ ile $\% 31$ 'inde objektif yant elde edilmekteydi $(5,6,7,8)$. $\mathrm{Bu}$ bulgular adjuvan immunoterapinin metastatik olmayan hastalarda da belli oranda yararlı olabileceğini düşündürdü ve RCC hastalarında birçok adjuvan immunoterapi çalışmasına ön ayak oldu. Fakat bu çalışmaların hiçbirinde adjuvan immunoterapi hastalıktan bağımsız ve genel sağkalımda anlamlı iyileşme saptayamadı $(9,10,11,12,13,14,15,16)$. Metastatik RCC tedavisinde immunoterapiye kıyasla belirgin sağkalım avantajı sağlayan hedefe yönelik tedavilerin kullanıma girmesi bu ajanların metastatik olmayan RCC'de adjuvan ve neoadjuvan olarak kullanımının sorgulanmasını sağlamıştır. Bu derlemede metastatik olmayan lokalize ve lokal ileri evre RCC'de adjuvan ve neoadjuvan hedefe yönelik tedavilerle ilgili sonuçlanan ve devam etmekte olan çalışmalar gözden geçirilecektir.

\section{Adjuvan Tedavinin Mantığı}

Giriş kısmında değinildiği üzere geçmiş yıllara nazaran daha çok hastanın evre I-III RCC olarak karşımıza çıkmasıyla beraber erken evrede yakalanan tümörlerin onkolojik tedavilerinin optimizasyonu ürolojik onkoloji ile ilgilenenler için öncelik kazanmaya başlamıştır. Özellikle orta-yüksek nüks riskine sahip hastalarda nüks oranlarını azaltarak sağkalımı uzatmak önemli bir hedeftir. Hastalık nüksü ve sağkalımı öngörebilen ve yaygın olarak kabul edilmiş bazı parametreler mevcuttur. Tanı anındaki T evresi prognoz için önemli göstergelerden biridir; nitekim pT4 evresindeki hastalarda 10 yıllık sağkalım oranı \%12'ye kadar düşmektedir ve eşlik eden lenf nodu tutulumuda nüks olasılığını belirgin şekilde arttırmaktadır (17). Evrenin yanında bazı histopatolojik özelliklerde kötü prognozla ilişkilidir. Berrak hücreli RCC tipi diğerlerine göre daha kötü kanser spesifik sağkalımla ilişkilidir; papiller ve kromofob tiplere kıyasla 3 kat mortalite riskine sahiptir (18). Nükleer derece artışı yine kötü prognozla ilişkili olup, 5 yıllık hastalığa bağlı sağkalım oranları geniş bir seride derece I, II, II ve IV için sırasıyla \%87,3, \%70,5, $\% 45,9$ ve $\% 14,9$ olarak saptanmıştır (19). Tümörde nekroz varlığı ve sarkomatoid farkılaşma kötü prognozla ilişkilidir $(20,21)$. Tümör özelliklerinin dışında hastaların performans durumunun da sağkalımla ilişkili olduğu; kötü performans skoru olan hastaların daha kötü prognoza sahip olduğu bilinmektedir (22). Hedefe yönelik tedavilerin metastatik hastalıkta gösterdiği başarı göz önüne alındığında yukarıda bahsedilen nüks riski yüksek olan veya kötü prognostik özelliklere sahip hastalarda cerrahi rezeksiyon sonrası adjuvan tedavinin faydalı olabileceği düşünülebilir, fakat bugün için kanıta dayalı tıp gözüyle baktığımızda kesin kanıt bulunmamaktadır. Devam eden çalışmalarda ise standardizasyonu sağlamak için kullanılan çeşitli risk sınıflamaları mevcut olup bunlar yazının ilerleyen kısmında gözden geçirilecektir.

\section{Adjuvan Tedavi için Risk Sınıflaması}

Adjuvan tedavi için doğru hasta seçimi büyük önem taşımaktadır. Nüks riski yüksek olan hastaların başarılı adjuvan tedavi seçeneklerinden fayda görebileceği düşünülebilir, bunun yanında gereksiz tedaviler de hastaları tedavinin riskleri ve istenmeyen yan etkileri ile karşı karşıya bırakabilir. RCC'de cerrahi rezeksiyon sonrası nüksü öngörmek için yukarıda bahsedilen özellikleri de içeren çok çeşitli nomogramlar geliştirilmiştir ve tamamlanmış ve devam etmekte olan adjuvan hedefe yönelik tedavi çalışmalarında kullanılmaktadır (Tablo 1) $(23,24,25,26,27,28,29)$. Bu nomogramlar genel olarak metastatik olmayan hastalıkta uzun dönemde hastalığın nüks riskini düşük, orta ve yüksek risk gruplarına ayırarak adjuvan tedavi ihtiyacı olan grubu belirlemeyi amaçlamaktadır. Metastatik olmayan RCC'de adjuvan tedavi çalışmaları genel olarak nüks açısından orta ve yüksek risk grubundaki hastaları çalışmalarına dahil etmektedir.

\section{Adjuvan Tedavi Çalışmaları}

Böbrek tümörlerinin moleküler biyolojisi ve patolojisinin daha iyi anlaşılması hedefe yönelik tedavilerin geliştirilmesini sağlamıştır. Tümör hücresinde bir tümör baskılayıcı gen olan Von Hippel Lindau (VHL) gen fonksiyonunda kayıpla birlikte başlayan ve devam eden kaskadda meydana gelen anormallikler berrak hücreli RCC ile ilişkilendirilmiştir (30). VHL kaybı hypoxiainduced factor (HIF) transkripsiyon faktöründe aktivite artışına, bu da sonuç olarak vascular endothelial growth factor (VEGF) ekspresyonunda artışa yol açmaktadır (31). HIF aktivitesi mammalian target of rapamycin (mTOR) yolağı aracılığıla da artabilmektedir (32). Bu da sonuçta VEGF'ye endotelyal yanıta bağlı olarak artmış tümör vaskülaritesine yol açar. Bu moleküler yolaklar temsirolimus ve everolimus gibi mTOR inhibitörleri, bevacizumab gibi VEGF monoklonal antikorları veya sorafenib, sunitinib, pazopanib gibi VEGF'nin endotelyal hücre içi sinyalllerini inhibe eden tirozin kinaz inhibitörleri (TKI) ile etkili şekilde devre dışı bırakılır (33). Bu küçük moleküllü hedefe yönelik tedavi seçeneklerinin oral biyoyararlanımı iyidir ve bu özellikleri geniş, çok merkezli adjuvan tedavi çalışmaları için kolaylık sağlayabilmektedir. Halihazırda metastatik olmayan RCC için devam etmekte olan yedi adet çok merkezli, plasebo kontrollü, çift-kör, randomize adjuvan tedavi çalışması bulunmaktadır. Bu çalışmaların detayları Tablo 2'de görülebilir.

\section{ARISER (NCT00087022)}

Bu çalışma bir karbonik anhidraz IX monoklonal antikoru olan girentuximabın RCC'de adjuvan etkinliğini araştırmaktaydı. Hasta alımı tamamlandı fakat çalışma primer sonlanım noktasına ulaşamadı. Tedavinin hastalıktan bağımsız sağkalım üzerine anlamlı bir etkisi olmadığı tespit edildi (34).

\section{ASSURE (NCT 00326898)}

Sorafenib ve sunitinibin etkinliğini karşılaştıran iki deneysel kollu bir çalışmadır. Primer sonlanım noktası hastalıktan bağımsız sağkalımdır. Çalışma devam etmekte ve 2016 yılı içerisinde tamamlanması beklenmektedir.

\section{ATLAS (NCT01599754)}

Bu çalışmada deneysel koldaki hastalara günde iki kez axitinib 5 mg verilmektedir. Primer sonlanım noktası hastalıktan bağımsız sağkalımdır. Nisan 2012'de hasta alımı başlamış olup 2017'de sonlanması beklenmektedir. 


\section{PROTECT (NCT01235962)}

Bu çalışmanın deneysel kolundaki hastalar günlük $800 \mathrm{mg}$ pazopanib almaktadır. Primer sonlanım noktası 4,5 yıllık takip sonrası hastalıtan bağımsız sağkalımdır. 2017 yılı içerisinde sonlanması beklenmektedir.

\section{SORCE (NCT00492258)}

Iki deneysel kolu olan bir çalışmadır. Hastalar cerrahi sonrası 1 veya 3 yıl sorafenib almaktadır. Çalışma öncesi nüks riski SSIGN skoru ile hesaplanmaktadır. Primer sonlanım noktası hastalıktan bağımsız sağkalımdır. Hasta alımı sonlanmış ve sonuçları beklenmektedir.

\section{S-TRAC (NCT00375674)}

Sunitinibin etkiniliğini değerlendiren bir çalışmadır. Nüks riskinin belirlenmesinde UISS skoru kullanılmıştır. Primer olarak hastalıktan bağımsız sağkalımı araştırmaktadır. İlk sonuçlar 2017 yllında beklenmektedir.

\section{SWOG-S0931 (EVEREST; NCT01120249)}

mTOR inhibitörü everolimusun adjuvan etkinliğini değerlendirmektedir. Tedavi kolu 12 ay boyunca everolimus almaktadır. Primer sonlanım noktası hastalıktan bağımsız sağkalımdır. Çalışma 2011 yılında başlamış olup 2021'den önce sonlanması beklenmemektedir.

Bu iyi planlanmış çalışmaların dışında metastatik olmayan RCC'de adjuvan hedefe yönelik tedavilerin değerlendirildiği tek merkezli bir çalışmada SSIGN skoruna göre nüks için yüksek riskli hastalarda adjuvan sorafenib ve sunitinib tedavilerinin etkinliği araştırılmışır (35). Hastalar sorafenib $(n=20)$, sunitinib $(n=23)$ ve kontrol grubu $(n=388)$ olarak üç grupta değerlendirmeye alınmış ve sonuç olarak nüks oranlarının tedavi alan grupta daha düşük $(\% 15, \% 17,4$ vs $\% 38,7)$ ve hastalıktan bağımsız sağkalım süresinin tedavi gruplarında kontrol grubuna göre daha uzun $(18,9 \pm 5,9,16,9 \pm 6,1$ vs $13,3 \pm 7,2$ ay) olduğu rapor edilmiş. Fakat çalışmanın retrospektif özelliği, kontrol grubunda çok daha fazla sayıda hasta olması, tedavi ve kontrol gruplarının aynı zaman diliminde olmayışı bu sonuçların değerlendirilmesini zorlaştırmaktadır.

\section{Neoadjuvan Tedavinin Mantığı}

Onkolojik açıdan bakıldığında solid tümörlerde neoadjuvan tedavinin amacı genel sağkalım ve hastalıktan bağımsız sağkalımı uzatmaktır. Bu durum RCC içinde geçerlidir. Hedefe yönelik tedavilerin metastatik RCC'de gösterdiği başarı bu ajanların metastatik olmayan RCC'de de neoadjuvan olarak kullanımını gündeme getirmiştir. Cerrahi açıdan bakıldığında ise beklenen faydalar; tümör boyutlarında küȩülme sağlayarak cerrahi olarak eksize edilemeyeceği düşünülen tümörleri eksizyon için uygun hale getirmek, cerrahinin morbiditesini azaltmak ve organ koruyucu cerrahiye olanak sağlamak olarak sıralanabilir.

\section{Neoadjuvan Tedavi Çalışmaları}

Metastatik olmayan RCC'de neoadjuvan hedefe yönelik tedavilerin bugün için genel sağkalım veya hastalıktan bağımsız sağkalım üzerine olan etkisini değerlendiren bir sonuç bulunmamaktadır. Yapılan çalışmalarda daha çok tümör boyutlarındaki küçülme, operasyona elverişli olmayan tümörlerin neoadjuvan tedavi sonrası opere edilebilirliği ve neoadjuvan tedavinin güvenliği değerlendirilmiştir. Operasyona elverişli olma tanımı tartışmalı bir konudur, çünkü cerrahın bireysel tecrübesine, teknik ekipman yeterliliğine ve gerektiğinde konsülte edilebilecek uzmanlık alanlarının (örneğin vena kava replasmanı veya geçici kardiyopulmoner by-pass için kardiyovasküler cerrahi konsültasyonu) varlığına bağlı olarak farklı merkezlerde

Tablo 1. Renal hücreli karsinomda cerrahi rezeksiyon sonrası nüksü öngörmek için geliştirilmiş olan nomogramlar ve skorlama sistemleri

\begin{tabular}{|c|c|c|c|}
\hline Prognostik Sistem & İçerik & Değerlendirdiği Parametre & Kaynak \\
\hline Kattan ve ark. (2001) & $\begin{array}{l}\text { Semptomlar } \\
\text { Histoloji } \\
\text { Tümör boyutu (1997) }\end{array}$ & 5 yıl nüks bağımsız sağkalım & 23 \\
\hline $\begin{array}{l}\text { Sorbellini ve ark. (2005) } \\
\text { (Berrak hücreli) }\end{array}$ & $\begin{array}{l}\text { Boyut } \\
\text { Nükleer derece } \\
\text { Nekroz } \\
\text { Vasküler invazyon } \\
\text { Semptomlar }\end{array}$ & 5 yıl nüks bağımsız sağkalım & 24 \\
\hline $\begin{array}{l}\text { Mayo Clinic } \\
\text { SSIGN }\end{array}$ & $\begin{array}{l}\text { TNM evresi (1997) } \\
\text { Nükleer derece } \\
\text { Nekroz }\end{array}$ & 10 yıl kanser spesifik sağkalım & 25 \\
\hline UISS & $\begin{array}{l}\text { TNM evresi (1997) } \\
\text { Fuhrmann derecesi } \\
\text { ECOG PS }\end{array}$ & 5 yıllık sağkalım & 26,27 \\
\hline $\begin{array}{l}\text { Leibovich ve ark. (2003) } \\
\text { (Berrak hücreli) }\end{array}$ & $\begin{array}{l}\text { TNM evresi (2002) } \\
\text { Nükleer derece } \\
\text { Nekroz }\end{array}$ & 10 yıl metastaz bağımsız sağkalım & 28 \\
\hline Karakiewicz ve ark. (2007) & $\begin{array}{l}\text { Semptomlar } \\
\text { Fuhrmann derecesi } \\
\text { Tümör boyutu } \\
\text { TNM evresi (2002) }\end{array}$ & 10 yıl hastalıktan bağımsız sağkalım & 29 \\
\hline
\end{tabular}


değişkenlikgösterebilmektedir. Neoadjuvan tedavi ile operasyona elverişli hale gelme konusunda günümüzdeki bilgiler genellikle metastatik hastalığı değerlendiren çalışmalardan gelmektedir. Bex ve ark. operasyona elverişli olmadığını düşündükleri metastatik RCC'li 10 hastadan 4 haftalık neoadjuvan sunitinib tedavisi sonrası 6 hastada primer tümörde Response evaluation criteria in solid tumours (RECIST) kriterlerine göre ortalama \%14 boyut azalması olduğunu tespit ettiler, hastaların yalnızca üçünde sitoredüktif nefrektomi kararı alındığı bildirildi (36). Lokal ileri evre veya metastatik 19 RCC'li hastanın değerlendirildiği bir başka çalışmada 4 haftalık sunitinib tedavisi ile hastaların yalnızca üçünde (\%16) kısmi yanıt alınırken, yedi hastada (\%37) primer tümör stabil kalmış ve dokuz hastada (\%47) tümörde progresyon saptanmıştır (37). Hastaların \%37'sinde sunitinib tedavisi ilişkili derece 3-4 toksisite geliştiği, altı aylık ortalama takipte bu hastaların dördüne sitoredüktif nefrektomi yapıldığı ve beş hastanın hastalık nedeniyle kaybedildiği raporlanmıştır. Rini ve ark. operasyona elverişli olmayan 30 hastayı (19'u metastatik) neoadjuvan 12 hafta, günlük 50 mg sunitinib sonrası değerlendirmiş ve hastaların \%45'inin tedavi sonrası opere edilebildiğini bildirmişlerdir (38). Bu çalışmanın bize verdiği farklı bir bilgide, berrak hücreli RCC (22/30) histolojisindeki

Tablo 2. Clinical Trials Database (http://clinicaltrials.gov) kayıtlı Renal hücreli karsinom için çok merkezli, plasebo kontrollü, randomize, çift kör adjuvan tedavi çalışmaları

\begin{tabular}{|c|c|c|c|c|c|c|c|c|}
\hline & Çalışma No & Statü & Tedavi & Dizayn & $\begin{array}{l}\text { Başlangıç/ } \\
\text { Tahmini } \\
\text { Bitiş Tarihi }\end{array}$ & $\begin{array}{l}\text { Hasta } \\
\text { Alım Kriterleri }\end{array}$ & $\begin{array}{l}\text { Tahmini } \\
\text { Hasta } \\
\text { Sayısı }\end{array}$ & $\begin{array}{l}\text { Sonuç } \\
\text { Ölçütleri }\end{array}$ \\
\hline ARISER & NCT00087022 & $\begin{array}{l}\text { Negatif } \\
\text { olarak } \\
\text { sonuçlandı }\end{array}$ & Girentuximab & $\begin{array}{l}\text { Çok merkezli, } \\
\text { çift kör, } \\
\text { randomiz, } \\
\text { plasebo kontrollü }\end{array}$ & $\begin{array}{l}07 / 2004 \\
10 / 2012\end{array}$ & $\begin{array}{l}\text { TN evresi veya } \\
\text { Fuhrmann } \\
\text { derecesine } \\
\text { göre yüksek } \\
\text { riskli } \\
\text { hastalar, } \\
\text { ECOG PS=0 } \\
\text { veya } 1\end{array}$ & 864 & DFS \\
\hline ASSURE & NCT00326898 & $\begin{array}{l}\text { Aktif, } \\
\text { hasta } \\
\text { alımı yok }\end{array}$ & $\begin{array}{l}\text { Sorafenib } \\
\text { veya } \\
\text { sunitinib }\end{array}$ & $\begin{array}{l}\text { Çok merkezli, } \\
\text { çift kör, } \\
\text { randomize, } \\
\text { plasebo kontrollü }\end{array}$ & $\begin{array}{l}05 / 2006 \\
04 / 2016\end{array}$ & $\begin{array}{l}\text { Orta-yüksek } \\
\text { risk UISS, } \\
\text { ECOG } \\
\text { PS=0 veya } 1, \\
\text { berrak } \\
\text { hücreli olan } \\
\text { ve olmayan }\end{array}$ & 1923 & $\begin{array}{l}\text { DFS, OS, } \\
\text { Toksisite, QoL }\end{array}$ \\
\hline ATLAS & NCT01599754 & $\begin{array}{l}\text { Hasta } \\
\text { alımı } \\
\text { devam } \\
\text { ediyor }\end{array}$ & Axitinib & $\begin{array}{l}\text { Çok merkezli, } \\
\text { çift kör, } \\
\text { randomize, } \\
\text { plasebo kontrollü }\end{array}$ & $\begin{array}{l}04 / 2012 \\
05 / 2019\end{array}$ & $\begin{array}{l}\text { Yüksek risk } \\
\text { UISS, } \\
\text { ECOG } \\
\text { PS=0 veya 1, } \\
\text { berrak hücreli }\end{array}$ & 592 & $\begin{array}{l}\text { DFS, OS, } \\
\text { Toksisite }\end{array}$ \\
\hline PROTECT & NCT01235962 & $\begin{array}{l}\text { Hasta } \\
\text { alımı } \\
\text { devam } \\
\text { ediyor }\end{array}$ & Pazopanib & $\begin{array}{l}\text { Çok merkezli, } \\
\text { çift kör, } \\
\text { randomize, } \\
\text { plasebo kontrollü }\end{array}$ & $\begin{array}{l}11 / 2010 \\
04 / 2017\end{array}$ & $\begin{array}{l}\text { Modifiye } \\
\text { UISS, } \\
\text { Karnofsky } \\
\text { performans } \\
\text { skoru } \geq 80 \text {, } \\
\text { berrak hücreli }\end{array}$ & 1500 & $\begin{array}{l}\text { OS, DFS, } \\
\text { Toksisite, QoL }\end{array}$ \\
\hline SORCE & NCT00492258 & $\begin{array}{l}\text { Hasta } \\
\text { alımı } \\
\text { devam } \\
\text { ediyor }\end{array}$ & Sorafenib & $\begin{array}{l}\text { Çok merkezli, } \\
\text { çift kör, } \\
\text { randomize, } \\
\text { plasebo kontrollü }\end{array}$ & $\begin{array}{l}05 / 2007 \\
05 / 2013\end{array}$ & $\begin{array}{l}\text { Orta-yüksek risk } \\
\text { SSIGN, ECOG } \\
\text { PS=0 veya 1, } \\
\text { berrak hücreli } \\
\text { olan ve olmayan }\end{array}$ & 1656 & $\begin{array}{l}\text { OS, DFS, } \\
\text { Toksisite }\end{array}$ \\
\hline S-TRAC & NCT00375674 & $\begin{array}{l}\text { Aktif, } \\
\text { hasta } \\
\text { alımı } \\
\text { yok } \\
\end{array}$ & Sunitinib & $\begin{array}{l}\text { Çok merkezli, } \\
\text { çift kör, } \\
\text { randomize, } \\
\text { plasebo kontrollü }\end{array}$ & $\begin{array}{l}07 / 2007 \\
06 / 2017\end{array}$ & $\begin{array}{l}\text { Yüksek risk UISS, } \\
\text { ECOG PS=0-2, } \\
\text { berrak hücreli }\end{array}$ & 720 & $\begin{array}{l}\text { DFS, OS, } \\
\text { Toksisite }\end{array}$ \\
\hline SWOG-S0931 & NCT01120249 & \begin{tabular}{|l|} 
Hasta \\
alımı \\
devam \\
ediyor
\end{tabular} & Everolimus & $\begin{array}{l}\text { Çok merkezli, } \\
\text { çift kör, } \\
\text { randomize, } \\
\text { plasebo kontrollü }\end{array}$ & $04 / 2011$ & $\begin{array}{l}\text { Patolojik yüksek } \\
\text { veya çok yüksek } \\
\text { risk, ECOG } \\
\text { PS=0 veya } 1\end{array}$ & 1218 & $\begin{array}{l}\text { OS, } \\
\text { DFS, Toksisite }\end{array}$ \\
\hline \multicolumn{9}{|c|}{ 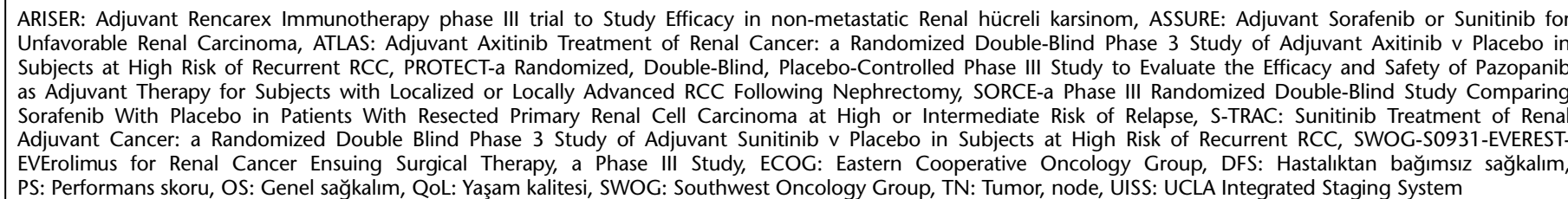 } \\
\hline
\end{tabular}


Bozkurt ve ark

Lokal Illeri Evre Böbrek Tümörlerinde Adjuvan ve Neoadjuvan Hedefe Yönelik Tedaviler

\begin{tabular}{|c|c|c|c|c|c|}
\hline $\begin{array}{l}\text { A study of neoadjuvant sunitinib for } \\
\text { patients with RCC }\end{array}$ & $\begin{array}{l}\text { Berrak hücreli, } \\
<7 \mathrm{~cm}\end{array}$ & Sunitinib & 30 & $\begin{array}{l}1 \text { kür neoadjuvan sunitinib ile } \\
\text { ilişkili radyolojik yanıt oranı }\end{array}$ & NCT00480935 \\
\hline Neoadjuvant pazopanib in RCC & $\begin{array}{l}\text { Berrak hücreli, } \\
>7 \mathrm{~cm}, \\
\mathrm{Nx}, \mathrm{MO}\end{array}$ & Pazopanib & 40 & $\begin{array}{l}\text { Lokal ileri evre RCC hastalarında } \\
12 \text { haftalı neoadjuvan pazopanib } \\
\text { tedavisi sonrası RECIST } \\
\text { kriterlerine göre objektif yanıt oranı }\end{array}$ & NCT01361113 \\
\hline $\begin{array}{l}\text { Neoadjuvant axitinib in locally } \\
\text { advanced RCC }\end{array}$ & $\begin{array}{l}\text { Berrak hücreli, } \\
\text { T2,T3N0M0 }\end{array}$ & Axitinib & 24 & $\begin{array}{l}\text { Tedavi sonrası } 12 \text {. haftada } \\
\text { BT ile değerlendirilecek } \\
\text { olan objektif yanıt oranı }\end{array}$ & NCT01263769 \\
\hline $\begin{array}{l}\text { Study of sunitinib in subjects with high } \\
\text { risk RCC }\end{array}$ & $\begin{array}{l}\mathrm{T} 1 \mathrm{~b}, \mathrm{~T} 2, \mathrm{~T} 3, \mathrm{~T} 4 \\
\text { and/or N1M0 }\end{array}$ & Sunitinib & 30 & $\begin{array}{l}\text { Yüksek riskli lokalize } \\
\text { RCC'de cerrahi sonrası } \\
\text { nükse kadar geçen süre }\end{array}$ & NCT01070186 \\
\hline
\end{tabular}

tümörlerde neoadjuvan tedavi ile primer tümör boyutunda ortanca \%28 azalma olurken, diğer histolojik tiplerde boyutta ortanca \%1,4'lük bir artış söz konusudur. Metastatik olmayan lokal ileri evre berrak hücreli RCC'de RECIST kriterlerine göre primer tümör yanıtının, yan etkilerin ve yaşam kalitesinin değerlendirildiği çok yeni bir çalışmada neoadjuvan 12 haftalık axitinib tedavisi değerlendirilmiştir (39). Çalışmaya dahil edilen 24 hastadan 22'si 12 haftalık tedaviyi tamamlamış, bir hasta 11 haftalık tedavi sonrası opere edilmiş, bir hasta ise 7 hafta sonra yan etkiler nedeniyle tedaviyi bırakmış. Primer böbrek tümöründe ortanca \%28,3 boyutsal azalma tespit edilmiş. On bir hastada RECIST kriterlerine göre kısmi yanıt elde edilirken, 13 hastada tümör stabildi. En sık gözlenen yan etkiler hipertansiyon, halsizlik, mukozit, hipotiroidizm ve el-ayak sendromu idi. Bütün hastalara tedavi sonrası cerrahın tercihine bağlı olarak açık veya laparoskopik radikal nefrektomi uygulandı. Clavien-Dindo sınıflamasına göre postoperatif dönemde 2 hastada 3. derece ve 13 hastada 2. derece komplikasyonla karşılaşıldı, 4. ve 5. derece komplikasyon gözlenmedi. Functional Assessment of Cancer Therapy-Kidney Specific Index-15 (FKSI-15) ile değerlendirilen yaşam kalitesinde tedavi sırasında 7. haftada belirginleşen bir azalma olsada bu durumun daha sonra düzeldiği bildirilmiş. RCC'de neoadjuvan tedavi ile ilgili diğer bir durum yüksek morbidite ve mortalite riski olan $\mathrm{T} 3 \mathrm{~b}$ ve $\mathrm{T} 3 \mathrm{c}$ hastalardır. Vena kava trombüsünün varlığı ile birlikte yukarı doğru uzanımıda perioperatif morbidite ve mortaliteyi belirleyen önemli faktörlerden birisidir (40). Trombüs atriuma ulaştığında perioperatif mortalite riski \%20 düzeyine kadar çıkabilmektedir (41). Bu durumda trombüs yükünün azaltılmasını sağlayacak bir tedavinin bununla ilişkili morbidite ve mortaliteyi azaltabileceği düşünülebilir. Kaval trombüsü olan hastalarda neoadjuvan hedefe yönelik tedavi ile ilgili birkaç olgu sunumunun $(42,43,44,45,46,47)$ yanında çok merkezli bir retrospektif vaka serisi analizi bugün için bize kısıtlıda olsa bazı bilgiler sağlamaktadır (48). Bu analizde evre II veya daha yüksek kaval trombüsü olan 25 hasta neoadjuvan tedavi sonrası tekrar değerlendirilmiş. Hastaların \%28'inde trombüs yüksekliğinde gözlenebilir artış saptanırken \%28'inde yükseklik stabil kalmış ve \%44'ünde azalma saptanmış. Trombüs derecelendirmesi açısında bakıldığında bir hastanın (\%4) derecesi yükselmiş (Evre
II'den Evre III'e), 21 hastanın derecesi değişmemiş (\%84) ve 3 hastanın derecesinde azalma (Evre IV iken Evre III; Evre III iken Evre II ve bir hastada da Evre II trombüs varken tedavi sonrası kaybolmuş) görülmüş (\%12). Aynı çalışmada primer tümör boyutunda 12 hastada küçülme (\%48) ve 10 hastada büyüme (\%40) saptanırken 3 hastada (\%12) değişiklik olmamış (48). $\mathrm{Bu}$ verilerden anlaşılacağı gibi bugün için vena kava trombüsü olan olgularda neoadjuvan hedefe yönelik tedavilerin yararı kısıtlıdır. Geniş hasta serilerinin değerlendirildiği prospektif kontrollü çalışmar bu konuda daha net fikir sahibi olmamızı sağlayacaktır.

Lokalize RCC'de neoadjuvan hedefe yönelik tedavilerle ilgili bir diğer merak edilen konu parsiyel nefrektomi için uygun olmadığı düşünülen olguların neoadjuvan tedavi ile uygun hale gelip gelmeyeceğidir. Bugün yaygın kabul görmüş bir gerçek vardır ki radikal nefrektomi kronik böbrek hastalığı için önemli bir risk oluşturmakta ve buna bağlı olarakta genel sağkalımda bir azalma söz konusu olabilmektedir. Bu nedenle özellikle son dekatta parsiyel nefrektomi T1a RCC için altın standart yöntem olmuştur, T1b tümörlerde de mümkün olan her durumda organ koruyucu cerrahi önerilmektedir (49). Fakat özellikle mutlak organ koruyucu cerrahi ihtiyacı olan soliter böbrekli veya bilateral RCC olgularında ayrı bir öneme sahiptir. Bu durumdaki hastalarda neoadjuvan hedefe yönelik tedavilerle ilgili olgu sunumları bize bu konuda az da olsa fikir vermektedir. Shuch ve ark. sol soliter böbrekli bir olguda 8,5 cm boyutunda bir RCC olgusunda 4 kür sunitinib ve 3 aylık sorafenib tedavisi sonrasında \%50'ye yakın bir tümör küçülmesi sonrası başarılı bir parsiyel nefrektomi olanağı bulduklarını ve hastanın böbrek fonksiyonları normal olarak taburcu edildiğini bildirmişlerdir (42). Thomas ve ark. lokal ileri evre RCC'li iki hastada neoadjuvan sunitinib tedavisi sonrası bir hastada bilateral parsiyel nefrektominin ve diğerinde kontralateral radikal nefrektomi ile birlikte unilateral parsiyel nefrektominin mümkün olduğunu bildirmişlerdir (50). Burada hatırlanması gereken; olgular yalnızca işler yolunda gittiğinde yazıya dökülür ve bu bilgilere dikkatle yaklaşmamız gerekmektedir. Bunun dışında bir cerrah için farklı nedenlerle (tecrübe, ekipman vb.) zor olan bir parsiyel nefrektomi bir diğer cerrah için çokta zor olmayabilir; bu da kafa karıştırıcı bir diğer neden olabilir. 
Silberstein ve ark. 12 hastalık bir seride (14 renal ünite) mutlak parsiyel nefrektomi öncesi neoadjuvan sunitinib tedavisinin etkisini değerlendirmişlerdir (51). Tedavi sonrası tümör boyutu ortalama 7,1 cm'den 5,6 cm'e düşmüş (\%21,1'lik küçülme) ve tüm hastalara başarılı şekilde parsiyel nefrektomi uygulanabilmiş (tüm hastalarda cerrahi sınırlar salim). Ortalama 23,9 aylık takipte bir hasta metastatik RCC nedeniyle kaybedilmiş, diğer hastaların hiçbirinde dializ gerekliliği olmamış. Yine de acaba bu hastalar neoadjuvan tedavi almamış olsalardı da aynı sonuçlara ulaşılabilirmiydi sorusunun yanıtı ne yazık ki bu çalışmanın sonuçları açısından kafa kurcalamaktadır. En azından ciddi bir yan etki veya komplikasyonla karşılaşılmamış olması hedefe yönelik tedavilerin bu hasta grubunda uygulanabilirliği açısından ümit vericidir. Bu kısıtlı bilgilerin dışında şu an devam etmekte olan prospektif kontrollü çalışmalar metastatik olmayan RCC'de neoadjuvan tedavinin kullanımı ve genel sağkalıma etkisi ile ilgili bizlere kanıt düzeyi daha yüksek bilgiler sağlayacaktır (Tablo 3).

\section{Sonuç}

Bugün için metastatik olmayan lokal ileri evre RCC'de adjuvan ya da neoadjuvan hedefe yönelik tedavilerin deneysel aşamada olduğu söylenebilir. Büyük tümörlerde ve mutlak organ koruyucu cerrahi gereken durumlarda neoadjuvan hedefe yönelik tedavi ile tümör boyutlarında küçülme sağlanarak hastaların operasyon için daha elverişli hale gelmesi nadiren de olsa mümkün olabilmektedir. Operasyon için uygun olmadığı düşünülen veya yüksek morbidite ve mortalite riski nedeniyle operasyonu kabul etmeyen bir hastanın bugün için bakıldığında zaten hedefe yönelik tedaviler dışında çok fazla bir seçeneği olmadığından, bu gibi durumlarda neoadjuvan tedavi ile tümör yanıtına bakılarak sonrasında hastanın operasyon açısından tekrar değerlendirilmesi uygun bir yaklaşım gibi görünmektedir. Lokalize ve lokal ileri evre RCC'de devam etmekte olan adjuvan ve neoadjuvan hedefe yönelik tedavi çalışmalarının sonuçları bize hem sağkalım hem de tedavi güvenliği açısından daha net bilgiler sağlayacaktır.

Çıkar çatışması: Yazarlar bu makale ile ilgili olarak herhangi bir çıkar çatışması bildirmemişlerdir.

\section{Kaynaklar}

1. Ferlay J, ShinH-R, Bray F, et al. Estimates of worldwide burden of cancer in 2008: GLOBOCAN 2008. Int J Cancer 2010;127:2893-2917.

2. Chow WH, Devesa SS, Warren JL, et al. Rising incidence of renal cell cancer in the United States. JAMA 1999;281:1628-1631.

3. Kane CJ, Mallin K, Ritchey J, et al. Renal cell cancer stage migration: analysis of the National Cancer Data Base. Cancer 2008; 113:78-83.

4. Escudier B, Eisen T, Porta C, et al. Renal cell carcinoma: ESMO Clinical Practice Guidelines for diagnosis, treatment and follow-up. Ann Oncol 2012;23:65-71.

5. Quesada JR, Swanson DA, Gutterman JU. Phase II study of interferon alpha in metastatic renal-cell carcinoma: a progress report. J Clin Oncol 1985;3:1086-1092.

6. Horoszewicz JS, Murphy GP. An assessment of the current use of human interferons in therapy of urological cancers. J Urol 1989;142:1173-1180.

7. Rosenberg SA, Yang JC, Topalian SL, et al. Treatment of 283 consecutive patients with metastatic melanoma or renal cell cancer using high-dose bolus interleukin 2. JAMA 1994;271:907-913.
8. Sleijfer DT, Janssen RA, Buter J, et al. Phase II study of subcutaneous interleukin-2 in unselected patients with advanced renal cell cancer on an outpatient basis. J Clin Oncol 1992;10:1119-1123.

9. Pizzocaro G, Piva L, Colavita M, et al. Interferon adjuvant to radical nephrectomy in Robson stages II and III renal cell carcinoma: a multicentric randomized study. J Clin Oncol 2001;19:425-431.

10. Messing EM, Manola J, Wilding G, et al. Phase III study of interferon alfa-NL as adjuvant treatment for resectable renal cell carcinoma: an Eastern Cooperative Oncology Group/Intergroup trial. J Clin Oncol 2003;21:1214-1222.

11. Clark JI, Atkins MB, Urba W], et al. Adjuvant high-dose bolus interleukin-2 for patients with high-risk renal cell carcinoma: a Cytokine Working Group randomized trial. J Clin Oncol 2003;21:3133-3140.

12. Passalacqua R, Buzio $C$, Buti $S$, et al. Adjuvant low-dose interleukin-2 (IL2) plus interferon-alpha (IFN) in operable renal cell cancer (RCC). A phase III, randomized, multicenter, independent trial of the Italian Oncology Group for Clinical Research (GOIRC). J Clin Oncol 2007 ASCO Annual Meeting Proceedings Part I. 2007; 25:18.

13. Atzpodien J, Kirchner $\mathrm{H}$, Illiger $\mathrm{HJ}$, et al. IL-2 in combination with IFNalpha and 5-FU versus tamoxifen in metastatic renal cell carcinoma: long-term results of a controlled randomized clinical trial. $\mathrm{Br}$ J Cancer 2001;85:1130-1136.

14. Atzpodien J, Kirchner $\mathrm{H}$, Jonas $\mathrm{U}$, et al. Interleukin-2- and interferon alfa2a-based immunochemotherapy in advanced renal cell carcinoma: a prospectively randomized trial of the German Cooperative Renal Carcinoma Chemoimmunotherapy Group (DGCIN). J Clin Oncol 2004;22:1188-1194.

15. Atzpodien J, Schmitt E, Gertenbach U, et al. Adjuvant treatment with interleukin-2- and interferon-alpha2a- based chemoimmunotherapy in renal cell carcinoma post tumour nephrectomy: results of a prospectively randomised trial of the German Cooperative Renal Carcinoma Chemoimmunotherapy Group (DGCIN). Br J Cancer 2005;92:843-846.

16. Aitchison M, Bray CA, Van Poppel H, et al. Preliminary results from a randomized phase III trial of adjuvant interleukin-2, interferon alpha and 5-fluorouracil in patients with a high risk of relapse after nephrectomy for renal cell carcinoma (RCC). J Clin Oncol 2008;26:5040 abstr.

17. Kim SP, Alt AL, Weight Cl, et al. Independent validation of the 2010 American Joint Committee on Cancer TNM classification for renal cell carcinoma: results from a large, single institution cohort. J Urol 2011; 185:2035-2039.

18. Leibovich BC, Lohse CM, Crispen PL, et al. Histological subtype is an independent predictor of outcome for patients with renal cell carcinoma. J Urol 2010;183:1309-1316.

19. Gudbjartson T, Hardarson S, Petursdottir V, et al. Histological subtyping and nuclear grading of renal cell carcinoma and their implications for survival: a retrospective nation-wide study of 629 patients. Eur Urol 2005;48:593-600.

20. Cheville JC, Lohse CM, Zincke $H$, et al. Comparisons of outcome and prognostic features among histologic subtypes of renal cell carcinoma. Am J Surg Pathol 2003;27:612-624.

21. de Peralta-Venturina $M$, Amin M, Tamboli $P$, et al. Sarcomotoid differentiation in renal cell carcinoma. Am J Surg Pathol 2001;25:275-284.

22. Flanigan RC, Polcari AJ, Hugen CM. Prognostic variables and nomograms for renal cell carcinoma. Int J Urol 2011;18:20-31.

23. Kattan MW, Reuter V, Motzer RJ, et al. A postoperative prognostic nomogram for renal cell carcinoma. J Urol 2001;166:63-67.

24. Sorbellini M, Kattan MW, Snyder ME, et al. A postoperative prognostic nomogram predicting recurrence for patients with conventional clear cell renal cell carcinoma. J Urol 2005;173:48-51. 
25. Frank I, Blute ML, Cheville JC, et al. An outcome prediction model for patients with clear cell renal cell carcinoma treated with radical nephrectomy based on tumor stage, size, grade and necrosis: the SSIGN score. J Urol 2001;168:2395-2400.

26. Zisman A, Pantuck AJ, Dorey F, et al. Improved prognostication of renal cell carcinoma using an integrated staging system. J Clin Oncol 2001;19:1649-1657.

27. Zisman A, Pantuck AJ, Wieder J, et al. Risk group assessment and clinical outcome algorithm to predict the natural history of patients with surgically resected renal cell carcinoma. J Clin Oncol 2002;20:4559-4566.

28. Leibovich BC, Blute ML, Cheville JC, et al. Prediction of progression after radical nephrectomy for patients with clear cell renal cell carcinoma. Cancer 2003;97:1663-1671.

29. Karakiewicz PI, Briganti A, Chun FK, et al. Multi-institutional validation of a new renal cancer-specific survival nomogram. J Clin Oncol 2007;25:1316-1322.

30. Latif F, Tory K, Gnarra J, et al. Identification of the von Hippel-Lindau disease tumor suppressor gene. Science 1993;260:1317-1320

31. Maxwell PH, Wiesener MS, Chang GW, et al. The tumour suppressor protein VHL targets hypoxia-inducible factors for oxygen-dependent proteolysis. Nature 1999;399:271-275.

32. Zhong H, Chiles K, Feldser D, et al. Modulation of hypoxiainducible factor 1alpha expression by the epidermal growth factor/ phosphatidylinositol 3-kin- ase/PTEN/AKT/FRAP pathway in human prostate cancer cells: implications for tumor angiogenesis and therapeutics. Cancer Res 2000;60:1541-1545.

33. Welsh S, Eisen T, Janowitz T. Focus on renal cancer. Antiangiogenesis in Cancer Therapy. 2013.

34. Pyrhoenen S, Board MA. Press release. WILEX AG announces results of phase III ARISER study with RENCAREX in clear cell renal cell carcinoma. 2012:1-3 October.

35. Zhao J, Zhu Y, Zhang C, et al. Sorafenib or sunitinib as postoperative adjuvant therapy for Chinese patients with locally advanced clear cell renal cell carcinoma at high risk for disease recurrence. Urol Oncol 2013;31:1800-1805.

36. Bex A, van der Veldt AA, Blank $C$, et al. Neoadjuvant sunitinib for surgically complex advanced renal cell cancer of doubtful resectability: initial experience with downsizing to reconsider cytoreductive surgery. World J Urol 2009;27:533-539.

37. Thomas AA, Rini BI, Lane BR, et al. Response of the primary tumor to neoadjuvant sunitinib in patients with advanced renal cell carcinoma. J Urol 2009;181:518-523.
38. Rini Bl, Garcia J, Elson P, et al. The effect of sunitinib on primary renal cell carcinoma and facilitation of subsequent surgery. J Urol 2012;187:1548-1554.

39. Karam JA, Devine CE, Urbauer DL, et al. Phase 2 Trial of Neoadjuvant Axitinib in Patients with Locally Advanced Nonmetastatic Clear Cell Renal Cell Carcinoma. Eur Urol 2014; http://dx.doi.org/10.1016/j. eururo.2014.01.035 [Epub ahead of print]

40. Karnes RJ, Blute ML. Surgery insight: management of renal cell carcinoma with associated inferior vena cava thrombus. Nat Clin Pract Urol 2008;5:329-339.

41. Shuch B, Crispen PL, Leibovich BC, et al. Cardiopulmonary bypass and renal cell carcinoma with level IV tumour thrombus: can deep hypothermic circulatory arrest limit perioperative mortality? BJU Int 2011;107:724-728.

42. Shuch B, Riggs SB, LaRochelle JC, et al. Neoadjuvant targeted therapy and advanced kidney cancer: observations and implications for a new treatment paradigm. BJU Int 2008;102:692-696.

43. Karakiewicz PI, Suardi N, Jeldres C, et al. Neoadjuvant sutent induction therapy may effectively down-stage renal cell carcinoma atrial thrombi. Eur Urol 2008;53:845-848.

44. Di Silverio F, Sciarra A, Parente U, et al. Neoadjuvant therapy with sorafenib in advanced renal cell carcinoma with vena cava extension submitted to radical nephrectomy. Urol Int 2008;80:451-453

45. Harshman LC, Srinivas S, Kamaya A, et al. Laparoscopic radical nephrectomy after shrinkage of a caval tumor thrombus with sunitinib. Nat Rev Urol 2009;6:338-343.

46. Robert G, Gabbay G, Bram R, et al. Case study of the month. Complete histologic remission after sunitinib neoadjuvant therapy in T3b renal cell carcinoma. Eur Urol 2009;55:1477-1480.

47. Bex A, Van der Veldt AA, Blank $C$, et al. Progression of a caval vein thrombus in two patients with primary renal cell carcinoma on pretreatment with sunitinib. Acta Oncol 2010;49:520-523.

48. Cost NG, Delacroix SE Jr, Sleeper JP, et al. The impact of targeted molecular therapies on the level of renal cell carcinoma vena caval tumor thrombus. Eur Urol 2011;59:912-918.

49. Ljungberg B, Cowan NC, Hanbury DC, et al. EAU guidelines on renal cell carcinoma: the 2010 update. Eur Urol 2010;58:398-406,

50. Thomas AA, Rini BI, Stephenson AJ, et al. Surgical resection of renal cell carcinoma after targeted therapy. J Urol 2009;182:881-886.

51. Silberstein JL, Millard F, Mehrazin R, et al. Feasibility and efficacy of neoadjuvant sunitinib before nephron-sparing surgery. BJU Int 2010;106;1270-1276. 